\title{
Protein Lyl-1
}

National Cancer Institute

\section{Source}

National Cancer Institute. Protein Lyl-1. NCI Thesaurus. Code C30097.

Protein lyl-1 (280 aa, $\sim 30 \mathrm{kDa}$ ) is encoded by the human LYL1 gene. This protein is involved in blood vessel maturation and transcriptional regulation. 